\title{
Activity enhancement of ammonia-oxidizing bacteria and nitrite-oxidizing bacteria in activated sludge process: metabolite reduction and $\mathrm{CO}_{2}$ mitigation intensification process
}

\author{
Arsalan Sepehri, ${ }^{1,2}$. Mohammad-Hossein Sarrafzadeh ${ }^{1}$
}

Received: 29 April 2019 / Accepted: 25 June 2019 / Published online: 5 July 2019

(c) The Author(s) 2019

\begin{abstract}
The interaction of ammonia-oxidizing bacteria (AOB) and nitrite-oxidizing bacteria (NOB) is of considerable importance in nitrification process. Ecophysiological interactions between the communities of AOB and NOB were investigated by monitoring $\mathrm{NO}_{2}{ }^{-}$as the intermediate compound in an organic carbon-depleted nitrifying activated sludge fed only $\mathrm{NH}_{4}{ }^{+}$ as a nitrogen source $(40 \mathrm{mg} / \mathrm{L})$. The presence of boom and bust (feast and famine) cycle successfully indicates the activity cycles of AOB and NOB through cultivation-dependent method. The maximum growth rate and yield for AOB in nitritation-dominant period were $\left(0.67 \mathrm{day}^{-1}, 0.17 \mathrm{gVSS} \mathrm{gN}^{-1}\right)$ and for NOB in nitratation-dominant period were $\left(0.71 \mathrm{day}^{-1}\right.$, $0.072 \mathrm{gVSS} \mathrm{gN}^{-1}$ ). Soluble microbial products (SMP) and extracellular polymeric substances (EPS) generated by AOB were 1.2 and $1.8 \mathrm{mg} / \mathrm{L}$, respectively, while NOB produced $0.6 \mathrm{mg} / \mathrm{L}$ of SMP and $1 \mathrm{mg} / \mathrm{L}$ of EPS. While NOB were low in utilization-associated products (UAP) $(0.07 \mathrm{mg} / \mathrm{L})$ and biomass-associated products (BAP) $(0.12 \mathrm{mg} / \mathrm{L})$, AOB were higher in $\mathrm{UAP}(0.15 \mathrm{mg} / \mathrm{L})$ and BAP $(0.3 \mathrm{mg} / \mathrm{L})$. The continuation presence of zero $\mathrm{C} / \mathrm{N}$ ratio, in either inlet ratio or net available ratio for the microbial community, can prolong and enhance nitratation process. NOB enrichment and nitratation intensification strategy through zero $\mathrm{C} / \mathrm{N}$ ratio are able to reduce remarkably microbial metabolites $50 \%$ lower than conventional process and enhance nitrification efficiency in activated sludge-involved processes.
\end{abstract}

Keywords Activated sludge $\cdot$ Nitrite $\cdot$ AOB $\cdot$ Fouling $\cdot$ NOB $\cdot$ Nitrification $\cdot$ SMP $\cdot$ EPS

$\begin{array}{ll}\text { Abbreviations } \\ \text { AOB } & \text { Ammonium oxidizing bacteria } \\ \text { BAP } & \text { Biomass-associated products } \\ \text { CAS } & \text { Conventional enriched activated sludge } \\ \text { C/N } & \text { Organic carbon to nitrogen loading rate } \\ \text { COD } & \text { Chemical oxygen demand } \\ \text { CTR }_{\text {meas }} & \text { Measured carbon dioxide uptake rate } \\ \text { DO } & \text { Dissolved oxygen } \\ \text { EPS } & \text { Exteracellular polymeric substance } \\ \text { HPR }_{\text {meas }} & \text { Hydrogen ion production rate }\end{array}$

Arsalan Sepehri

arsalan.sepehri@ rockets.utoledo.edu

$\triangle$ Mohammad-Hossein Sarrafzadeh

sarrafzdh@ut.ac.ir

1 UNESCO Chair on Water Reuse, School of Chemical Engineering, College of Engineering, University of Tehran, P.O. Box: 11155-4563, Tehran, Iran

2 Department of Chemical Engineering, University of Toledo, Toledo, OH 43606, USA
NAS Nitrifier enriched activated sludge

NOB Nitrite-oxidizing bacteria

$r_{\mathrm{NH}_{3}} \quad$ Rate of ammonium consumption

$r_{\mathrm{NO}_{2}^{-}} \quad$ Rate of nitrite accumulation

$r_{\mathrm{NO}_{3}^{-}} \quad$ Rate of nitrate production

$r_{\mathrm{O}_{2}} \quad$ Rate of oxygen consumption

SMP Soluble microbial products

TOGA Titrimetric and offgas analyzer

UAP Utilization-associated products

$Y_{\mathrm{A}} \quad$ Yield (subscript $1=$ nitritation; subscript

$2=$ nitratation)

$\mu_{\text {Amax }} \quad$ Maximum growth rate

\section{Introduction}

Biological treatment is widely used for municipal and industrial wastewaters (Massot et al. 2012). The microbial metabolites produced during biological treatment in the forms of soluble microbial products (SMP) and extracellular 
polymeric substances (EPS) are mainly composed of proteins, carbohydrates, and humic substances (Kunacheva et al. 2017). These metabolites create a residual organic matter in secondary effluent (Zhang et al. 2017). Due to their impacts on the physio-chemical properties of microbial aggregates in the sludge, SMP are considered as major sludge floc component leading to keep the floc in a matrix. Conversely, these major components are viewed as the key foulant causing irreversible biofouling of membrane bioreactors. During the post-treatment process, SMP and EPS are regarded as precursors for disinfection by-products, which aggravates the treatment process (Krasner et al. 2009; Shariati et al. 2013). Therefore, microbial metabolites are undergoing a revolution in terms of research focus in the field of environmental biotechnology.

Previous studies (Xie et al. 2012; Dolinšek et al. 2013) focused on unified theory which explains the growth of heterotrophic bacteria supported by nitrifiers as primary producers. The theory indicates the supporting microbial growth mechanism via the give-and-take between autotrophs and heterotrophic bacteria through the production of utilization-associated products (UAP), biomass-associated products (BAP) by autotrophs and carbon dioxide production by heterotrophs. Figure 1 shows the summary of unified theory which points out autotrophic and heterotrophic collaboration for assimilation ( $\mathrm{Ni}$ et al. 2011). On the contrary, competition between heterotrophs and nitrifiers for terminal electron acceptor $\mathrm{O}_{2}$ and the production rate of total biomass not only establish a complicated interdependent microbial network but also can influence on SMP and EPS generation (Hunt et al. 2018). Relative population of autotrophs and heterotrophs depends heavily on $\mathrm{C} / \mathrm{N}$ ratio available to microbial community. Under different operational conditions such as HRT, SRT, DO concentration, temperature, and substrate concentration the responses of autotrophic nitrifiers are divergent, which in turn influence metabolite production (Hu et al. 2003). In low $\mathrm{C} / \mathrm{N}$ ratios, nitrifiers dominate heterotrophs and enhance the nitrification efficiency (Ma et al. 2013). Ammonia-oxidizing bacteria (AOB) and nitrite-oxidizing bacteria (NOB), contributors of two phylogenetically unassociated congregations of lithoautotrophic bacteria, perform nitrification process via a symbiosis interaction. The limiting step in nitrification process generally is attributed to the nitritation process (Carrera et al. 2003; Su 2012; Raimonet et al. 2015; Silva et al. 2018; Zeng et al. 2018). Besides the thermodynamic limitation and competition of heterotrophs with nitrifier for oxygen and space, $\mathrm{AOB}$ compete with NOB for oxygen and alkalinity. As a result, elimination of external organic carbon by adjusting $\mathrm{C} / \mathrm{N}$ ratio to zero can resolve the inhibitory role of heterotrophs in nitrification (Ma et al. 2013).

Dissecting nutrient flow through AOB to NOB is a nontrivial task which needs to detect the uptake and assimilation of substrates such as $\mathrm{NH}_{4}{ }^{+}$and $\mathrm{NO}_{2}{ }^{-}$(Kindaichi et al. 2004). To optimize nitrification efficiency, the growth balance between $\mathrm{AOB}$ and NOB become a vital factor especially
Fig. 1 Interaction of $\mathrm{AOB}$, $\mathrm{NOB}$, and heterotrophs according to the unified theory

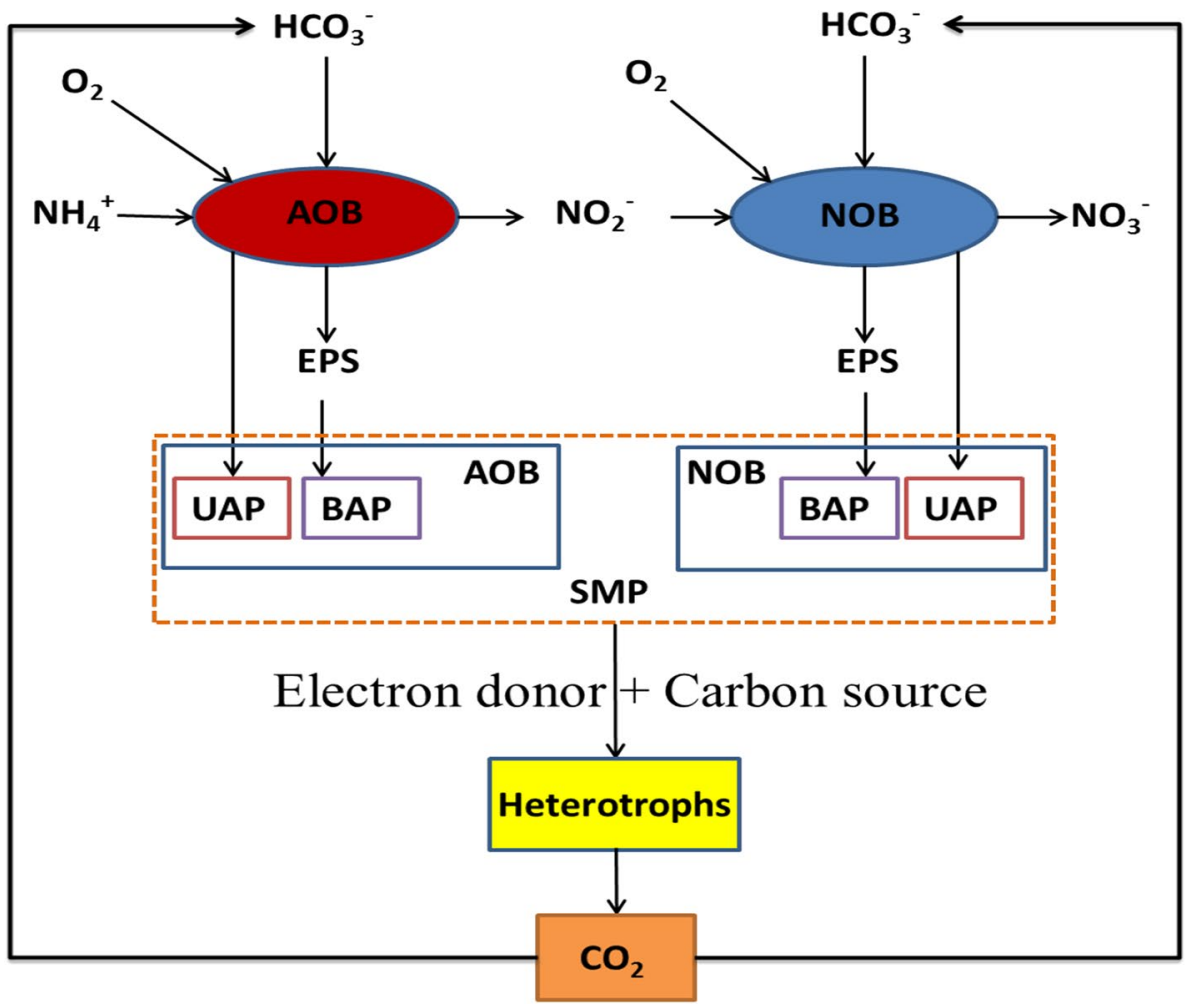


when the advanced water treatment process is used (Yao and Peng 2017). This balance can be adjusted through regulation of nitratation process.

It would be also beneficial to analyze the distribution of metabolites in AOB and NOB since the pattern of these distributions can provide significant hints about the nature and specificity of complicated interactions between $\mathrm{AOB}$ and NOB in flocs as well as biofilms. Metabolite distribution in nitrification can be highly significant especially in $\mathrm{N}$-riched advanced wastewater treatment processes. A neglected area in the field of autotrophic nitrification led to the question of how specific such complicated interactions might be employed in order to minimize EPS and SMP without compromising assimilation.

In the present study, we have developed an innovative solution to specifically investigate two theories: (1) growth detection of AOB and NOB by cross-feeding of NOB by AOB through a viable non-molecular analysis; (2) quantification of different microbial metabolites by AOB and NOB based on unified theory in the N-riched media.

\section{Materials and methods}

\section{Nitrifiers enrichment through particular feeding method}

Enrichment of nitrifiers was conducted using the inorganic feed to activated sludge, which was obtained from local municipal wastewater treatment plant during 75 days. In order to monitor the growth of nitrifiers, performances of nitrifier-enriched activated sludge (NAS) and conventional activated sludge (CAS) were compared in terms of nitrification efficiency and COD removal in the batch mode. Nitrification efficiency in NAS and CAS was $100 \%$ vs. $43 \%$, while the COD removal in NAS and CAS was $9 \%$ vs. $65 \%$. Detecting different parameters such as alkalinity, $\mathrm{pH}$, and nitrate also fortified the enrichment of nitrifiers. More data regarding the enrichment process are found in the related paper (Sepehri and Sarrafzadeh 2018).

\section{Process description and bioreactor set-up}

In order to monitor and distinguish the growth of AOB and NOB, a Plexiglas airlift reactor with a working volume of $20 \mathrm{~L}$ was selected. The internal diameter was $15 \mathrm{~cm}$, and height of the reactor was $100 \mathrm{~cm}$. In order to measure energy solely through chemical oxidation, the reactor was opaque in color. It is significant to know that the bioreactor was equipped with a thermostatic jacket and temperature was maintained at $30 \pm 0.5{ }^{\circ} \mathrm{C}$. Air was supplied through an air diffuser connected to an air pump. Aeration density was monitored and controlled via an airflow meter to keep DO concentration at 3-4 mg/L. For the sake of keeping SRT at 7 days, the extra sludge volume was discharged manually from the bioreactor every day. The discharged volume was replaced with the synthetic wastewater. The initial part of the experiment due to a divergence in the behavior of microbial community from conventional activated sludge was conducted for 28 days.

\section{Operational conditions for growth of AOB and NOB}

The bioreactor was seeded with NAS. Initially, mixed liquor suspended solid was kept at $2000 \mathrm{mg} / \mathrm{L}$. The $\mathrm{pH}$ of synthetic wastewater and the activated sludge was stabilized at $7-7.3$ by supplying bicarbonate salt $\left(\mathrm{NaHCO}_{3}\right)$. The bioreactor was fed with synthetic wastewater including $40 \mathrm{mg} / \mathrm{L}$ $\mathrm{N}-\mathrm{NH}_{4}{ }^{+}$and sufficient alkalinity $\left(5.95 \mathrm{~g} \mathrm{NaHCO}_{3}\right.$ ) during 75 days. The synthetic wastewater contains $\left(\mathrm{NH}_{4}\right) \cdot \mathrm{SO}_{4}$, $\mathrm{NaH}_{2} \mathrm{PO}_{4} \cdot \mathrm{H}_{2} \mathrm{O}, \mathrm{NaHCO}_{3}$, and $1 \mathrm{~L}$ of trace metal solution: EDTA $(10 \mathrm{~mL}), \mathrm{ZnSO}_{4} \cdot 7 \mathrm{H}_{2} \mathrm{O}(2.20 \mathrm{~mL}), \mathrm{CoCl}_{2} \cdot 6 \mathrm{H}_{2} \mathrm{O}$ $(3.20 \mathrm{~mL}), \mathrm{MnCl}_{2} \cdot 4 \mathrm{H}_{2} \mathrm{O}(10.20 \mathrm{~mL}), \mathrm{CuSO}_{4} \cdot 5 \mathrm{H}_{2} \mathrm{O}$ $(0.22 \mathrm{~mL})\left(\mathrm{NH}_{4}\right)_{6} \mathrm{Mo}_{7} \mathrm{O}_{24} \cdot 4 \mathrm{H}_{2} \mathrm{O}(2.20 \mathrm{~mL}), \mathrm{CaCl}_{2} \cdot 2 \mathrm{H}_{2} \mathrm{O}$ $(1.10 \mathrm{~mL}), \mathrm{FeSO}_{4} \cdot 7 \mathrm{H}_{2} \mathrm{O}(10.00 \mathrm{~mL}), \mathrm{H}_{3} \mathrm{BO}_{3}(0.30 \mathrm{~mL})$, $\mathrm{NiSO}_{4} \cdot 6 \mathrm{H}_{2} \mathrm{O}(1.00 \mathrm{~mL})$. In order to enhance nitrification efficiency, $\mathrm{C} / \mathrm{N}$ ratio in the feed was retained at zero. Variations of all nitrogen compounds, as well as microbial metabolites, were monitored daily. In order to monitor the growth and metabolite building up through AOB and NOB, a control experiment enriched with CAS was conducted along with NAS. Additional information regarding the control experiment is located in the related paper (Sepehri and Sarrafzadeh 2018).

\section{Determination of growth parameters using $\mathrm{CO}_{2}$ uptake and nitritation and nitratation rate: validation strategy for enrichment of $A O B$ and NOB in attributed phases}

In this study, the growth parameters including $\mu_{\max }$ and $Y_{A}$ were calculated based on the results of the titrimetric and offgas analyzer (TOGA) method proposed by Blackburne et al. (2007). At the end of each phase, the sludge was transferred to TOGA. Briefly, TOGA has a closed reactor filled with target biomass at the end of each phase of growth. Titrimetric $\mathrm{pH}$ meter controls acidity in the system by adjusting hydrochloric acid and sodium hydroxide dosing pump. The amount of acid/base usage in the reactor is recorded as the rate of proton accumulation in the processes occurring in bioreactor. The measure of gas concentration in feed gas along with offgas leads in gas components transfer rates in the gas phase mass balance. Oxygen transfer rate (OTR) can be used when the transfer of oxygen reaches equilibrium. The carbon dioxide uptake rate $\left(r_{\mathrm{CO}_{2}}\right)$ is found by measured carbon dioxide transfer rate $\left(\mathrm{CTR}_{\text {meas }}\right)$ and hydrogen

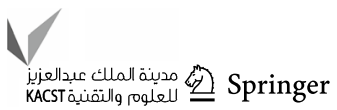


ion production rate $\left(\mathrm{HPR}_{\text {meas }}\right)$. When $\mathrm{HPR}_{\text {meas }}$ is positive, it shows production of hydrogen ion. The below-mentioned equations show the mathematical equations for $\mathrm{HPR}_{\text {meas }}$ and $r_{\mathrm{CO}_{2}}$ :

$r_{\mathrm{CO}_{2}}=\left(\mathrm{HPR}_{\text {meas }}-r H+\frac{r_{\mathrm{NH}_{3}}}{1+10^{\mathrm{pH}-\mathrm{pKn}}}\right)\left(1+10^{(\mathrm{pKa}-\mathrm{pH})}+\mathrm{CTR}_{\text {meas }}\right.$

Below we summarized each rates for nitrification steps:

Nitritation process:

$$
\begin{aligned}
& r_{\mathrm{NH}_{3}}=\left(\frac{1}{Y_{A_{1}}}+i_{X B}\right) r_{A_{1}} \\
& r_{\mathrm{O}_{2}}=\left(\frac{1.5}{Y_{A_{1}}}-1\right) r_{A_{1}} \\
& r_{\mathrm{CO}_{2}}=r_{A_{1}}=r_{X} \\
& r_{\mathrm{NO}_{2}^{-}}=\frac{1}{Y_{A_{1}}} r_{A_{1}}=r_{\mathrm{H}^{+}}
\end{aligned}
$$

Nitratation process:

$$
\begin{aligned}
& r_{\mathrm{NH}_{3}}=i_{X B} r_{A_{2}} \\
& r_{\mathrm{O}_{2}}=\left(\frac{0.5}{Y_{A_{2}}}-1\right) r_{A_{2}} \\
& r_{\mathrm{CO}_{2}}=r_{A_{2}}=r_{X} \\
& r_{\mathrm{NO}_{2}^{-}}=\frac{1}{Y_{A_{2}}} r_{A_{2}} \\
& r_{\mathrm{NO}_{3}^{-}}=\frac{1}{Y_{A_{2}}} r_{A_{2}}
\end{aligned}
$$

Nitrification process (Nitritation + Nitratation)

$$
\begin{aligned}
& r_{\mathrm{NH}_{3}}=\left(\frac{1}{Y A}+i_{X B}\right) r_{A} \\
& r_{\mathrm{O}_{2}}=\left(\frac{2}{Y_{A}}-1\right) r_{A} \\
& r_{\mathrm{CO}_{2}}=r_{A}=r_{X} \\
& r_{\mathrm{H}^{+}}=\frac{1}{Y_{A 1}} r_{A 1} \\
& r_{\mathrm{NO}_{3}^{-}}=\frac{1}{Y_{A}} r_{A}
\end{aligned}
$$

\section{Measurement techniques for substrates and metabolites in biological reactors}

Samples were taken from the bioreactor at the beginning and end of every day and were immediately centrifuged for the analysis of $\mathrm{N}-\mathrm{NH}_{4}{ }^{+}, \mathrm{N}-\mathrm{NO}_{2}{ }^{-}, \mathrm{N}-\mathrm{NO}_{3}{ }^{-}, \mathrm{EPSc}$, EPSp, SMPc, SMPp, UAP, and BAP. The concentrations of MLSS, N- $\mathrm{NH}_{4}^{+}, \mathrm{N}-\mathrm{NO}_{2}{ }^{-}$and $\mathrm{N}-\mathrm{NO}_{3}{ }^{-}$were measured in accordance with the standard methods for examination of water and wastewater (Rice et al. 2012). pH was monitored using a pH probe (240, ISTEK, Korea), and dissolved oxygen (DO) was monitored by DO sensor (WTW340i, Germany). In order to determine the amount of $\mathrm{N}-\mathrm{NH}_{4}{ }^{+}, \mathrm{N}-\mathrm{NO}_{2}{ }^{-}$, and $\mathrm{N}-\mathrm{NO}_{3}{ }^{-}$, Agilent $8453 \mathrm{UV}-\mathrm{Vis}$ spectrophotometer was utilized at $640 \mathrm{~nm}$ for $\mathrm{NH}_{4}{ }^{+}$, at 275 and $220 \mathrm{~nm}$ for $\mathrm{NO}_{3}{ }^{-}$, and at $543 \mathrm{~nm}$ for $\mathrm{NO}_{2}{ }^{-}$.

Protein parts (EPSp, SMPp) and carbohydrate parts (EPSc, SMPc) of SMP and EPS were measured based on the method proposed by Le-Clech et al. (2006). The SMP values in the supernatant were measured through consecutive centrifuging of microbial samples at $5000 \mathrm{~g}$ for $5 \mathrm{~min}$ and filtration process of the remaining supernatant. The mixing process was done after adding deionized water to the samples for $10 \mathrm{~min}$. A series of heating and centrifuging processes were put and placed in order to remove impurities. The heating and centrifuging processes were carried out at $80^{\circ} \mathrm{C}$ and $7000 \mathrm{~g}$ during a 10 -min span. The EPS content in both forms was measured through supernatant filtration process.

The fresh activated sludge sample was washed and transferred to another bioreactor equipped with a heater in order to maintain temperature around $20^{\circ} \mathrm{C}$. BAP was measured without the addition of substrate, whereby BAP dominated microbial products as proposed by Jiang et al. (2008). Thirty milliliter of sludge sample was collected from the bioreactor and soluble COD and EPS measured daily. The BAP production rate was calculated from the variation in EPS concentration. In the direction of quantifying the UAP content values, the sludge was spiked with $2 \mathrm{~L}$ of ultra-filtered wastewater. The wastewater was filtered through a $0.45-\mu \mathrm{m}$ membrane. Next, the wastewater underwent an ultrafiltration membrane (PLAC cellulosic disks, MWCO, $1000 \mathrm{Da}$, Millipore Inc., USA) in order to concentrate the soluble degradable substrate (Xie et al. 2016). 


\section{Results and discussion}

\section{Detecting the growth of $A O B$ and NOB via a consecutive boom and bust cycle and nitrogen transformation}

$\mathrm{N}-\mathrm{NO}_{2}{ }^{-}$, intermediate compound in nitrification and a dependable parameter quantifying the intensity and degree of nitritation and nitratation, was detected as a response. Nitrite is recognized as an unstable nitrogen compound and can easily be converted to nitrate. Various studies have shown that the accumulation of nitrite in the environment is rarely observed because of two reasons: (1) a higher substrate utilization rate of nitrite oxidizers than ammonia oxidizers and (2) a low $S_{\min }$ (minimum required substrate concentration in order to support microbial community) (Kim et al. 2008). Nitrite accumulation was observed in some specific environmental conditions such as high temperature (Kim et al. 2008). Variation of $\mathrm{N}-\mathrm{NH}_{4}{ }^{+}, \mathrm{N}-\mathrm{NO}_{2}{ }^{-}$and $\mathrm{N}-\mathrm{NO}_{3}{ }^{-}$is shown in Fig. 2. It must be taken into account that the initial concentration of $\mathrm{N}-\mathrm{NH}_{4}{ }^{+}$and $\mathrm{N}-\mathrm{NO}_{3}{ }^{-}$was 40 and $10 \mathrm{mg} / \mathrm{L}$, respectively. The results in Fig. 2 yielded some valid findings, which consisted of two stages. The datasets for the first stage span the period from zero to the 5th day and for the second stage from 5th to 7th day. A cursory glance at Fig. 2 reveals that a particular pattern occurred in the bioreactor. A reasonable explanation for the periodical cycle could be based on the first step in nitrification. The overall downward trend in $\mathrm{N}-\mathrm{NH}_{4}{ }^{+}$ species concentrations confirms the effective occurrence of nitritation process throughout the entire operation of the bioreactor. The maximum amounts of nitrite build-up are $30,33,34$ and $35 \mathrm{mg} / \mathrm{L}$ which occurred in 5th day of each week. The trend of nitrite accumulation correlates favorably with Kim et al. (2008) and further supports the idea that nitrifiers were activated and dominated in NAS and making the results to be interpretable based on nitrite-dependent point of view. The observed increase in nitrite until the 5th day in each week could be attributed to the dominant activity of AOB (seen as the shoulder) since the nitritation process leads to nitrite accumulation. According to Fig. 2, there exists a negative correlation between ammonium and nitrite concentration in nitritation-dominant period. A reasonable explanation for such correlation might be the complete ammonium removal. AOB were able to convert all ammonium before the 5th day of the last months of enrichment. According to Fig. 2, in the 6th day, AOB did not have access to ammonium. Similarly, the observed decrease in nitrite from 5 th to the 7 th day could be interpreted as being a result of the dominant activity of NOB since the accumulation of both nitrite and nitrate confirms their activity. Final nitrite concentrations at the end of each batch are $3.76,3.22,2.64$ and $1.79 \mathrm{mg} / \mathrm{L}$. In the five first days of each week in view of the fact that there was not enough nitrite production, the NOB cannot acquire essential energy from the oxidation of little-produced nitrite. Due to nitrite production by $\mathrm{AOB}$, the nutritional condition was proper for the activity of NOB. After the 5th day, NOB completely converted all of the nitrite to nitrate. It was depicted above that the amount of nitrite production was largely determined by the amount of ammonium concentration in the reactor. Dytczak et al. (2008) analyzed the influence of nitrite concentration on ammonium utilization rate in batch condition and demonstrated up to $35 \mathrm{mg} \mathrm{N}-\mathrm{NO}_{2}{ }^{-}$caused no inhibition for activity of AOB. According to Dytczak results, nitrifier can prolong nitritation and nitratation periodical cycles without suppression due to nutrient shocks. The data provide convincing evidence demonstrating that nitrite is a key component of a link between AOB and NOB. According to the nitrite results, reaching to maximum nitrite takes 5 days and
Fig. 2 Monitoring the symbiosis interaction of $\mathrm{AOB}$ and NOB through the non-molecular approach (consecutive boom and bust cycles): $\mathrm{N}-\mathrm{NO}_{2}{ }^{-}$along with $\mathrm{N}-\mathrm{NH}_{4}{ }^{+}$and $\mathrm{N}-\mathrm{NO}_{3}{ }^{-}$profiles can elucidate the enrichment of nitrifiers in a sludge sample

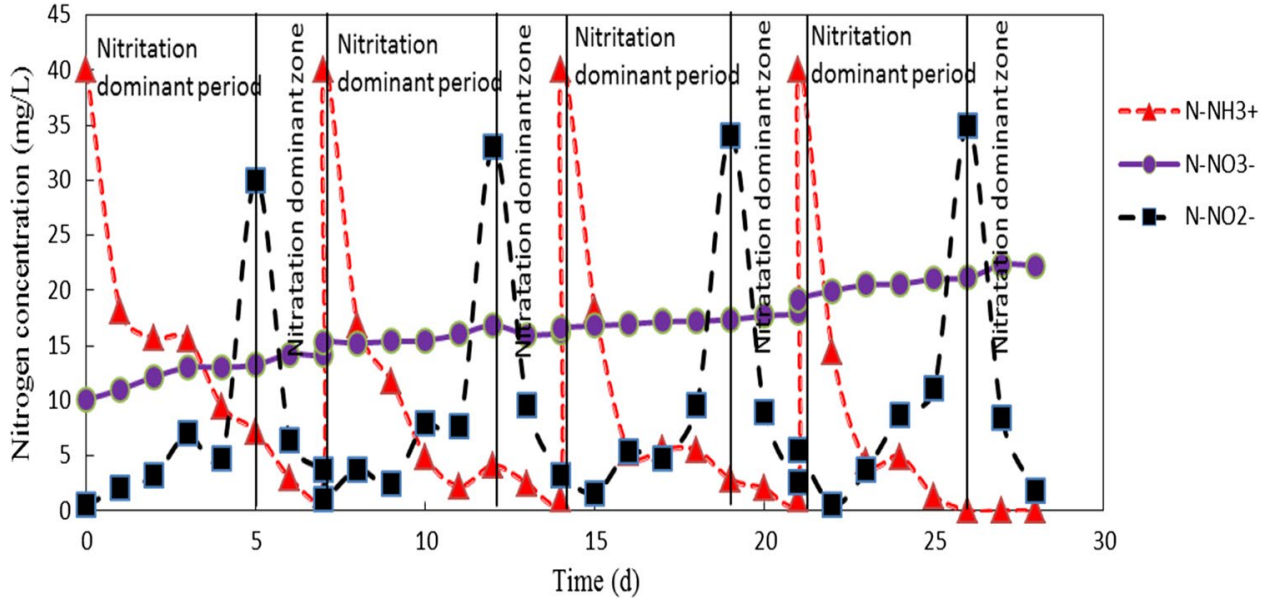


reaching to minimum nitrite takes 2 days in each week, which shows the longer nitritation than nitratation process. The longer nitritation process is consistent with the literature. Kim et al. (2008) found that in the temperature ranges $20-30{ }^{\circ} \mathrm{C}$ activation energy of nitritation is $87.1 \mathrm{~kJ} \mathrm{~mol}^{-1}$ and activation energy for nitratation is $38.6 \mathrm{~kJ} \mathrm{~mol}^{-1}$. According to the Kim results, nitritation is the rate-limiting step that the nitrite trend in Fig. 2 validates their results. Kowalchuk and Stephen (2001) also studied the microbial behavior of AOB and mentioned chemolithoautotrophic AOB are responsible for the rateliming step of nitrification in a variety of environments. Collectively, these findings implicate evidently the distinguishable phases for the dominant activity of $\mathrm{AOB}$ and NOB during the batch tests. These consecutive cycles provide an authentic methodology to quantify the growth of AOB and NOB distinctively. In addition, the observed production and consumption of nitrite along with parallel ammonium utilization and nitrate generation in oxic period can be assigned to the collaboration between AOB and NOB. The repeated cycle of nitrite occurred in NAS is called "Boom and Bust" or "feast and famine" in ecological science.

"Boom" is characterized by the rapid growth and activity of one species that is followed by "Bust" during which the activity of dominant species falls back to a minimal level. The noticeable depletion of ammonium concentration and production of nitrate through the occurrence of the boom and bust cycle promote the idea that AOB and NOB are the dominant active species in the community. Microbial community in NAS provided a comparable response during boom and bust cycle. Based on current data, for the first 5 days, aerobic nitrifiers consistent with Nitrosomonas are better competitor, while for two final days of each phase the alternating bacteria identified as Nitrobacter would proliferate.

\section{Evaluation of dominant period in terms of alkalinity consumption}

Nitrification is a well-known biological reaction in alkalinity consumption (Sepehri and Sarrafzadeh 2018). As a result, $\mathrm{pH}$ of activated sludge reduces. In order to validate the dominant period, alkalinity consumption was measured. From 0 day to 5 th day, $5.2 \mathrm{~g} \mathrm{NaHCO}_{3}$ was used on average through 4 weeks. On contrary, from 5 th day to 7 th day, $1.3 \mathrm{~g}$ $\mathrm{NaHCO}_{3}$ was used on average through 4 weeks to compensate alkalinity requirement for biological activity. Comparison between these values for alkalinity consumption substantiates the division between nitritation-dominant period and nitratation-dominant period. Theoretically, alkalinity consumption through nitritation is higher than nitratation since there is not hydrogen ion produced through nitratation (Peng and Zhu 2006).

\section{Determining $Y_{\mathrm{A}}$ and $\mu_{\mathrm{Amax}}$ from nitrogen oxidation rate}

The main kinetic coefficients for microbial growth measurements are maximum growth rate $\left(\mu_{\mathrm{Amax}}\right)$ and yield $\left(Y_{\mathrm{A}}\right)$. The presence of boom and bust cycles can distinguish the growth parameters related to both $\mathrm{AOB}$ and NOB independently. To study nitrifiers growth more precisely, values for $\mu_{\mathrm{Amax}}$ and $Y_{\mathrm{A}}$ were calculated. Nitrifiers growth parameter was calculated according to the method proposed by Blackburne et al. (2007) through the rate of carbon dioxide uptake and rate of oxygen rate and $\mathrm{NH}_{4}{ }^{+}$(or nitrite) utilization. Table 1 summarizes the obtained values in the current study and values quoted in the literature. Independent phases represent different weeks in which growth of nitrifiers occurred. $\mu_{\mathrm{Amax}}$ and $Y_{\mathrm{A}}$ values demonstrated in Table 1 concur well with Melcer (2004) findings regarding the temperature-adjusted values to $30{ }^{\circ} \mathrm{C}$ applying the coefficient $1.076^{(T-20)}$. The consistency of growth parameters values with the previous

Table 1 Growth parameters of AOB and NOB after nitrifiers enrichment during 75 days. Values were determined at temperature of $30{ }^{\circ} \mathrm{C}$

\begin{tabular}{|c|c|c|c|c|c|}
\hline Experiment number & $\begin{array}{l}\mu_{\text {Amax }} \\
\left(\text { days }^{-1}\right)(\mathrm{AOB})\end{array}$ & $\begin{array}{l}Y_{\mathrm{A}} \\
\left(\mathrm{gVSS} \mathrm{gN}^{-1}\right)(\mathrm{AOB})\end{array}$ & $\begin{array}{l}\mu_{\text {Amax }} \\
\left(\text { days }^{-1}\right)(\mathrm{NOB})\end{array}$ & $\begin{array}{l}Y_{\mathrm{A}} \\
\left(\mathrm{gVSS} \mathrm{gN}^{-1}\right)(\mathrm{NOB})\end{array}$ & $\begin{array}{l}T_{d} \\
\text { (day) }\end{array}$ \\
\hline Phase 1: (0-7th day) & 0.510 & 0.16 & 0.683 & 0.072 & 1.66 \\
\hline Phase 2: (7th-14th day) & 0.523 & 0.17 & 0.632 & 0.062 & 1.62 \\
\hline Phase 3: (14th-21th day) & 0.440 & 0.18 & 0.630 & 0.063 & 1.58 \\
\hline Phase 4: (21th-28th day) & 0.670 & 0.17 & 0.710 & 0.072 & 1.50 \\
\hline Vadivelu et al. $(2006 \mathrm{a}, \mathrm{b})\left(30^{\circ} \mathrm{C}\right)$ & 1.000 & 0.12 & 0.480 & 0.071 & n.a. \\
\hline Keen and Prosser $(1987)\left(30^{\circ} \mathrm{C}\right)$ & 0.936 & n.a. & 1.032 & n.a. & n.a. \\
\hline Blackburne et al. (2007) & $0.48-0.65$ & $0.11-0.18$ & $0.66-0.68$ & $0.062-0.081$ & n.a. \\
\hline
\end{tabular}

The values for phase 1 to phase 4 correspond to the mean value adjusted to $30^{\circ} \mathrm{C}$ applying the relation $1.079^{(T-20)}$

n.a. Not available in the literature 
study in the literature suggests feasibility and efficacy of the defined method with full-scale activated sludge. The presence of a subtle difference in the obtained values and literature values can be due to operational parameters. A significant difference was associated with the contrast in two important parameters including temperature and $\mathrm{pH}$. These parameters profoundly influenced the growth rate of AOB and NOB. Vadivelu et al. (2006a b) determined the value of $Y_{\mathrm{A}}=0.071 \mathrm{gVSS} \mathrm{gN}^{-1}$ and $\mu_{\mathrm{Amax}}=0.48$ days $^{-1}$ for NOB enriched community at temperature $22^{\circ} \mathrm{C}, \mathrm{pH}$ 7.3. According to the Water Research Commission (Ekama et al. 1984), the correction factor for $\mathrm{pH}$-adjusted values is $2.35^{(\mathrm{pH}-7.2)}$. They designed activated sludge processes for nutrient removal. In this particular study due to the growth of nitrifiers bacteria, the factor for $\mathrm{pH}$ correction was $2.9^{(\mathrm{pH}-7.1)}$. Another explanation for the difference in growth parameter can also be attributed to either the production of microbial metabolites such as SMP and EPS or the energy requirement of cell maintenance (Fang et al. 2009). An additional source of error might be accumulation of carbon dioxide/bicarbonate in nitrifiers community in order to achieve the bicarbonate equilibrium which results in generation of protons into the activated sludge (Blackburne et al. 2007).

\section{Microbial metabolites generated by the activity of $A O B$ and NOB in the consecutive boom and bust cycles}

\section{SMP and EPS production by $A O B$ and $N O B$}

The minimum $\mathrm{C} / \mathrm{N}$ ratio and thereafter $\mathrm{AOB}$ and NOB abundance in bioreactor displayed significant influence onto the sludge EPS, and bulk supernatant SMP. In order to investigate the process in terms of metabolite production, the profiles of EPS and SMP are illustrated in Figs. 3 and 4. Extracellular protein concentration (Fig. 3a) increased in either nitritation or nitratation processes during 28 days of growth. AOB under $\mathrm{N}-\mathrm{NH}_{4}{ }^{+}$enriched conditions yielded $0.95 \mathrm{mg} / \mathrm{L}$ EPSp after 28 days of growth compared to $0.4 \mathrm{mg} / \mathrm{L}$ for
Fig. 3 Quantitative analysis of microbial metabolite synthesis of $\mathrm{AOB}$ and $\mathrm{NOB}$ under boom and bust cycle after enrichment: a variation in $\triangle \mathrm{EPSp}$ and total EPSp generation, $\mathbf{b}$ variation in $\triangle$ EPSp and total EPSp generation
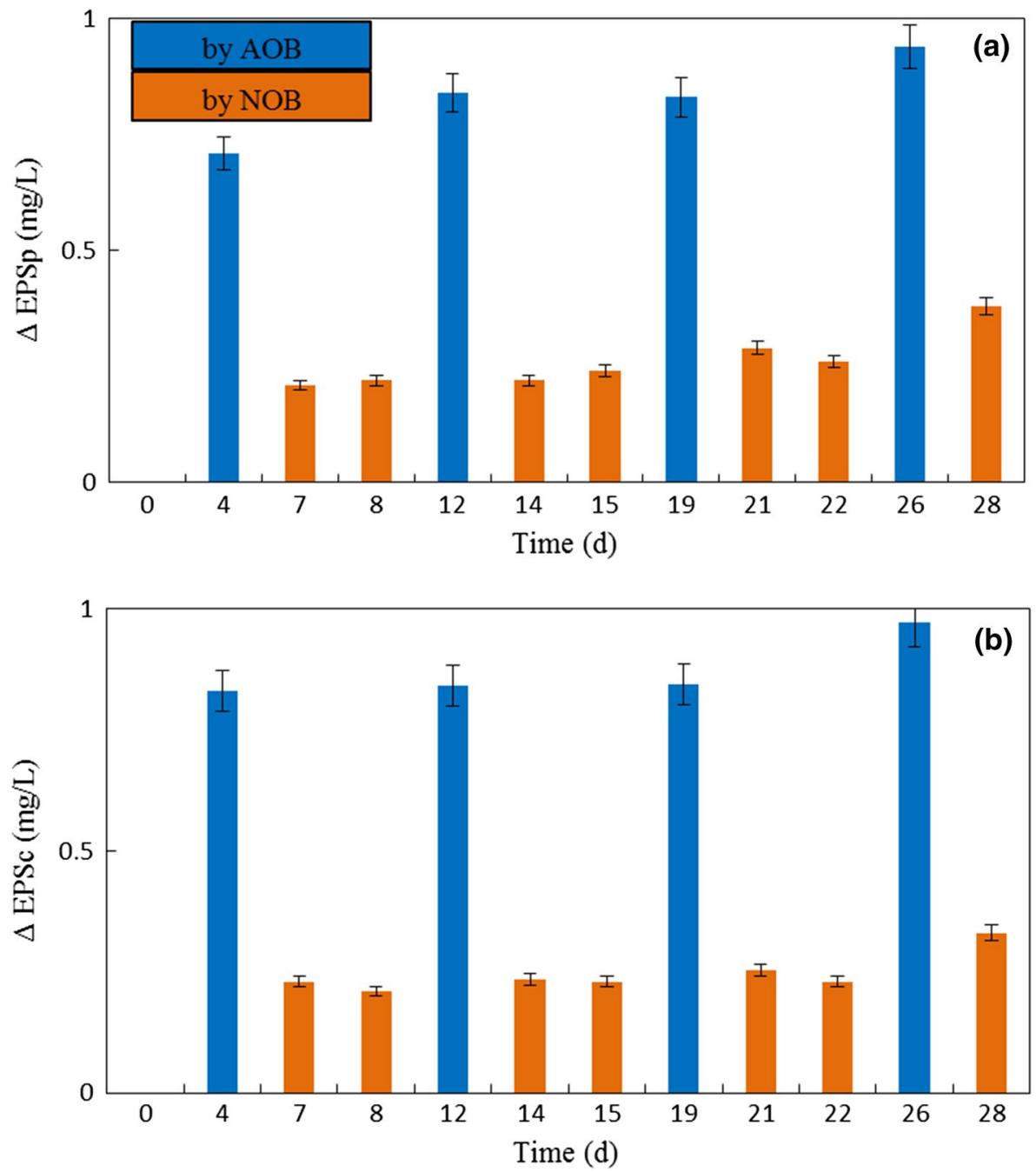

Time (d) 
Fig. 4 Bulk supernatant soluble microbial products and their fraction in batch test after $\mathrm{AOB}$ and NOB enrichment through non-molecular approach: a variation in $\triangle \mathrm{SMPp}$ and total SMPp generation. b Variation in $\triangle \mathrm{SMPc}$ and total SMPc generation
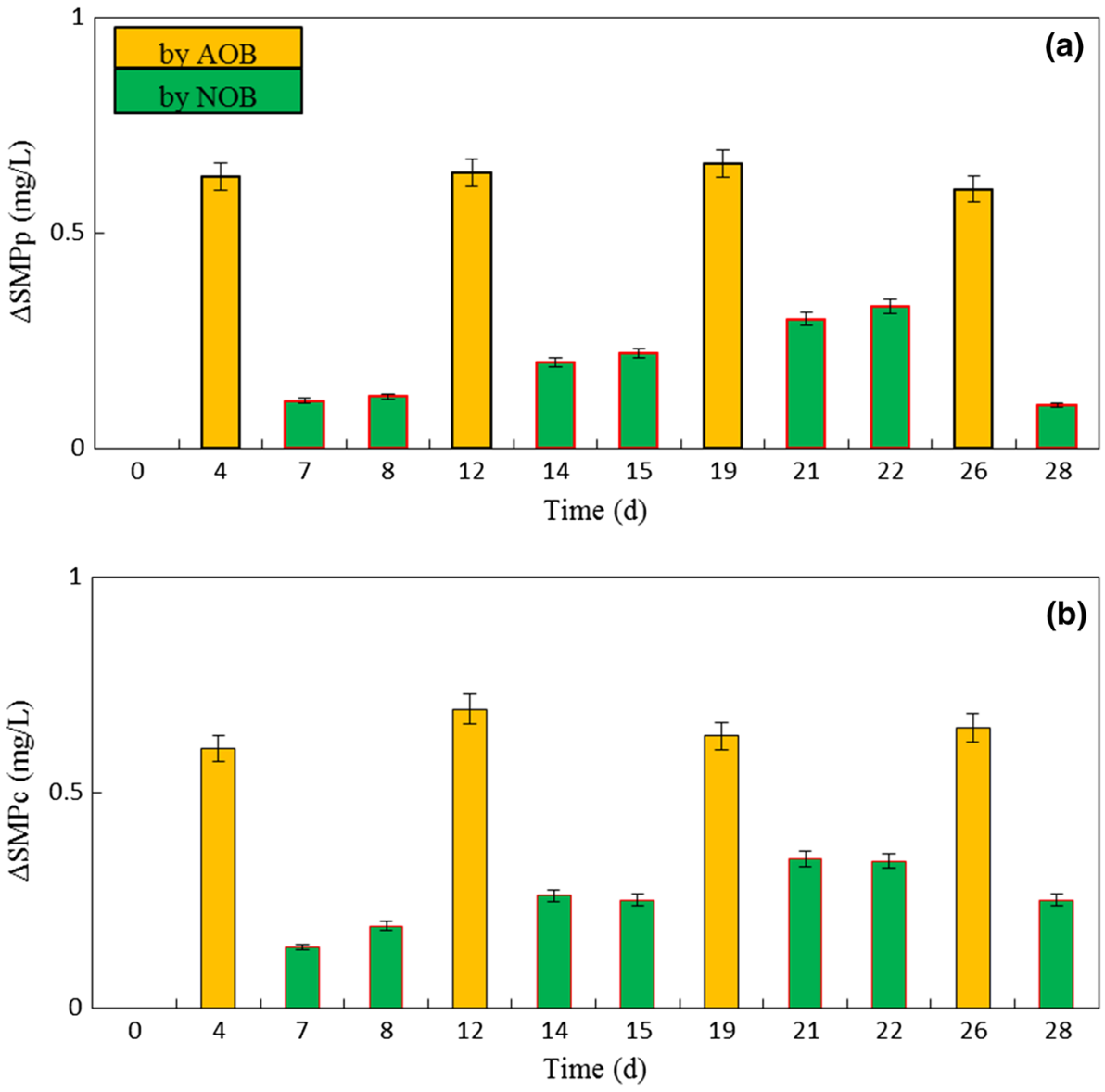

$\mathrm{N}-\mathrm{NO}_{2}{ }^{-}$enriched conditions. The specific production of EPS, including protein and carbohydrates, was more than that of SMP. When AOB abundance increased continuously, the $\triangle$ EPSp content increased from 0.7 to $0.92 \mathrm{mg} / \mathrm{L}$. The $\Delta$ EPS and $\triangle$ SMP and their component fractionalized as carbohydrates and protein-like substances in the bioreactor were relatively stable during the whole experiment time. Compared with the relatively stable $\triangle E P S$ content by $\mathrm{AOB}$ and NOB, a continuous elevation of $\triangle \mathrm{SMPc}$ as well as $\triangle \mathrm{SMPp}$ content with an increase of $\mathrm{AOB}$ and NOB community occurred in the bioreactor (Fig. 4a, b). However, the elevation of $\triangle \mathrm{SMPc}$ as well as $\triangle \mathrm{SMPp}$ content for AOB was substantially higher than NOB in nitrifiers-enriched activated sludge. The probable reason for higher metabolite production by AOB might be related to the kinetic of nitritation and nitratation processes. Soluble microbial products (SMP) and extracellular polymeric substances (EPS) generated by AOB were 1.2 and $1.8 \mathrm{mg} / \mathrm{L}$, respectively, while NOB produced $0.6 \mathrm{mg} / \mathrm{L}$ of SMP and $1 \mathrm{mg} / \mathrm{L}$ of EPS.

The kinetics of the second step of nitrification could be controlled by different parameters such as availability of substrates, oxygen concentration (shear rate), and SRT (Mertoglu et al. 2006). However, the very different amounts of nitrite also affect the nitrifying community. In the bioreactor with nitrite accumulation shows that oxidation rate by $\mathrm{AOB}$ was faster than NOB. Therefore, there is the least time for NOB to exert EPS and SMP. Jia et al. (1996) investigated the influence of cultivation time on EPS generation in activated sludge and showed that EPS level could be closely related to the microbial growth phase. Here, the cultivation time, according to the all nitrogen variation compounds can confirm higher cultivation time for AOB compared to NOB. Another probable reason for a higher metabolite of $\mathrm{AOB}$ might be due to the shear rate of the bioreactor. The shear rate or aeration intensity could have more influence on the EPS content in sludge (Adav et al. 2008). Oxygen concentration influences the distribution of $\mathrm{AOB}$ and $\mathrm{NOB}$ in environmental systems. Schramm et al. findings proved oxygen concentration can be a limiting factor manipulating activity and abundance of nitrifiers. Schramm et al. (1996) demonstrated dependability of Nitrosomonas and Nitrobacter species on oxygen through $K_{\mathrm{m}}$ (substrate affinities by Michaelis-Menten kinetics) values for oxygen. In addition, nitrifiers establish rather compact and dense colonial structure. Schramm et al. concluded that under low oxygen tension, NOB was out-competed by AOB. In another study, Okabe et al. (1999) observed that AOB strains can tolerate the low oxygen concentration. According to the 
above-mentioned researches, the availability of oxygen for $\mathrm{NOB}$ was lower than $\mathrm{AOB}$ and resulted in an environmental stress. Therefore, AOB metabolism that was higher than NOB led to a larger portion of organic metabolite synthesis. Another reason for higher metabolite generation by AOB may be due to the limited SRT. Xie et al. (2013) showed the positive correlation between organic released metabolites values and SRT.

\section{Quantification of UAP and BAP by AOB and NOB}

Variations of UAP and BAP were monitored in order to have a clearer view of AOB and NOB microbial behavior. Significant progress has been recently made to differentiate quantitatively and accurately UAP and BAP. Characterization of UAP and BAP was conducted according to the unified theory. According to this theory, UAP are built up during assimilation, and BAP are built up through hydrolysis of biomass content (Ni et al. 2011). Formation of BAP is achieved at a rate proportional to the EPS concentration. Total EPS hydrolysis coefficient determines the amount of BAP produced by AOB and NOB. The UAP and BAP content values of the AOB and NOB reported, compared well with values in the literature (Xie et al. 2012). The BAP content of sludge samples was observed to be higher than that of UAP. In order to validate UAP and BAP values, control experiments with conventional activated sludge process were done in the previous study. The results of EPSt and SMPt generation via conventional activated sludge enriched with heterotrophs (Fig. 5) demonstrated the substantially higher amount of metabolites than generated by nitrifiers (Sepehri and Sarrafzadeh 2018). As can be seen in Fig. 6, BAP concentration increased steadily and linearly from 1.3 to $2.6 \mathrm{mg} / \mathrm{L}$ and formed the main component of SMP mainly after the first week. BAP accounts for more than $92 \%$ of SMP on average. The values correlate satisfactorily with Xie et al. (2012) and further support the idea that metabolites of AOB and NOB are much lower than heterotrophic bacteria. Figure 6 demonstrates that there exists four consecutive nitritation and nitratation process during the whole experiment. The produced amount of UAP and BAP by NOB initially was similar to AOB. After 2 weeks, these values for AOB exceeded from NOB. While NOB were low in utilization-associated products (UAP) $(0.07 \mathrm{mg} / \mathrm{L})$ and biomass-associated products (BAP) $(0.12 \mathrm{mg} / \mathrm{L})$, AOB were higher in UAP $(0.15 \mathrm{mg} / \mathrm{L})$ and $\mathrm{BAP}(0.3 \mathrm{mg} / \mathrm{L})$. One of the significant differences in the values of UAP and BAP could be due to the initial source of their generation. Since the source of UAP is carbonaceous compounds from the substrate and the source of BAP cellular macromolecules containing organic carbon and nitrogen, generation of BAP is expected to be higher (Jarusutthirak and Amy 2006; Merkey et al. 2009). In addition, the colonies of NOB are mainly less dense than AOB cluster and in general NOB colonies and cells are more uniformly distributed compared to AOB colonies. These values offer overwhelming evidence for higher metabolism and metabolite production by AOB. The results suggest that moving the microbial community toward NOB enrichment and confining the growth of AOB can lead to lower organic metabolite in the effluent.

Barker and Stuckey (1999) demonstrated that through closing a mass balance on SMP using radio-active ${ }^{14} \mathrm{C}$ tracer, BAP generation is related to the biomass decay stoichiometrically. Nevertheless, their assessment failed to take into account the EPS component of biomass. The results demonstrate the importance of reduction of metabolites and addressing the parameters influencing the production of the metabolites. One of the governing
Fig. 5 Generation of SMPt and EPSt in the conventional activated sludge enriched with heterotrophs
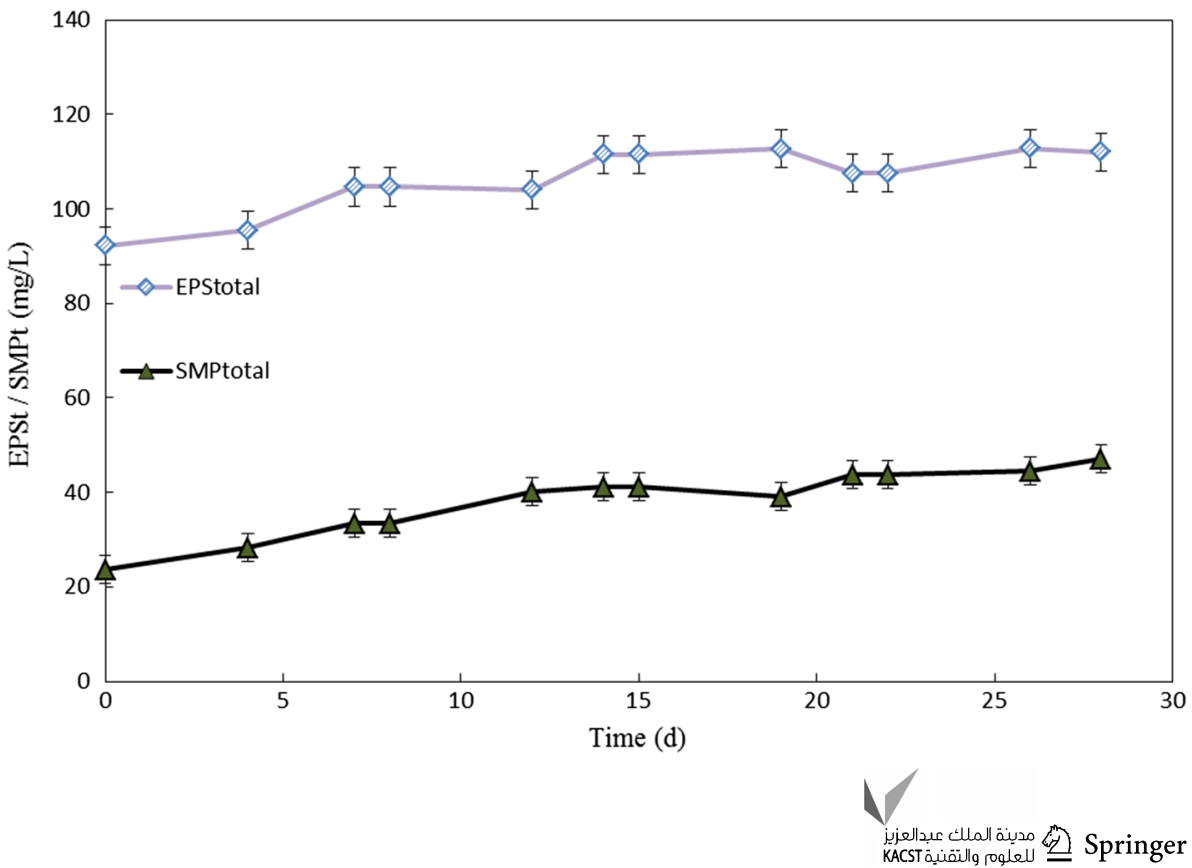


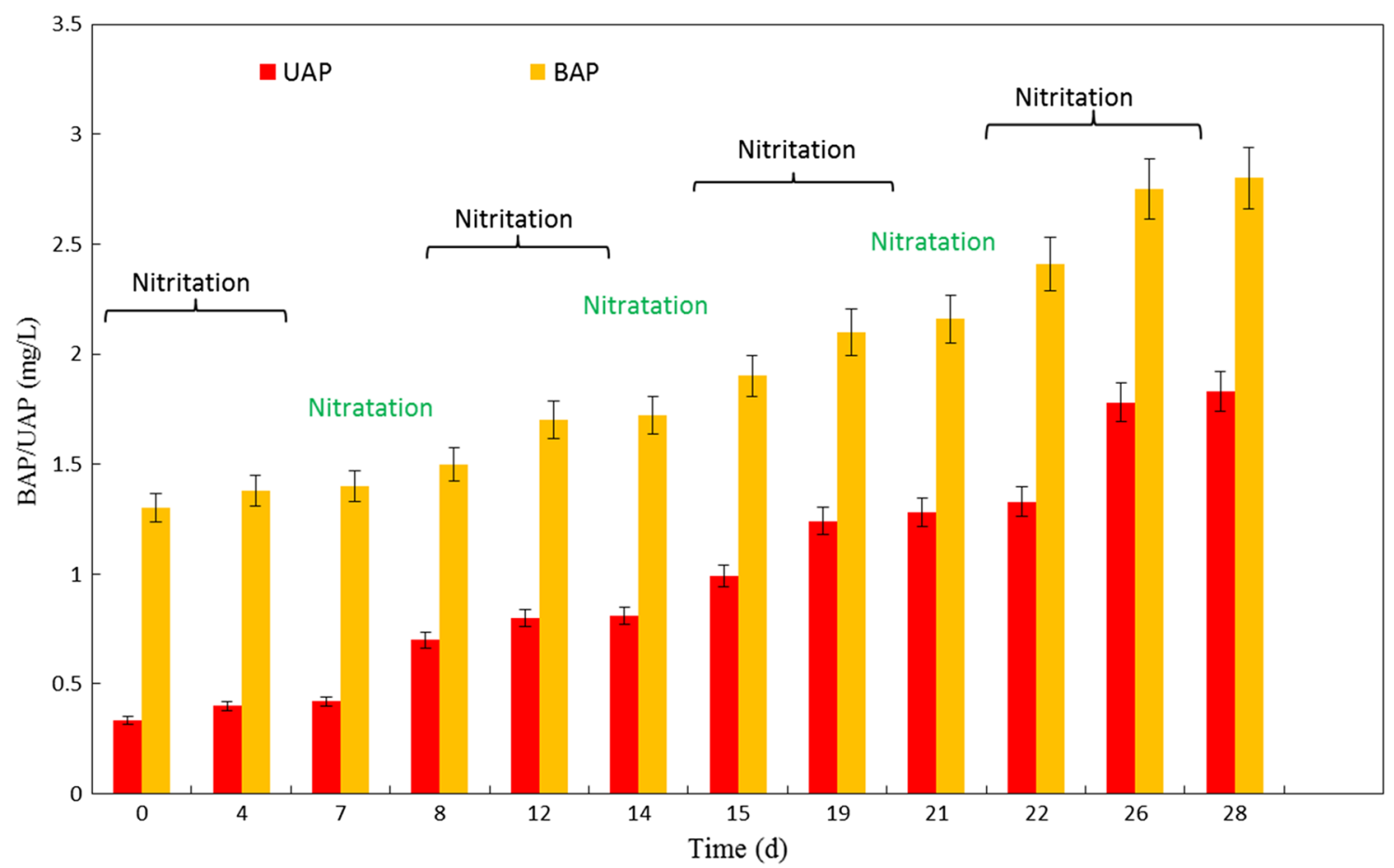

Fig. 6 Responses of BAP, UAP, total SMP, and total EPS through nitritation-dominant period and nitratation-dominant period. The presence of positive correlation between BAP and nitrification and a negative correlation between UAP and nitrification process elucidate the symbiosis interaction of $\mathrm{AOB}$ and $\mathrm{NOB}$ in batch mode

metabolites are precursors for chlorinated organic compound such as trihalomethanes in tertiary treatment.

\section{Conclusion}

In this study, monitoring the growth of $\mathrm{AOB}$ and $\mathrm{NOB}$ was performed through the development of a viable nonmolecular approach. To control the microbial metabolites, a method was recommended which is strengthened by nitratation intensification process. Nitrite as an intermediate component, which links AOB and NOB, was detected during 28 days after enrichment. The presence of boom and bust cycle (feast-famine cycle) in nitrogen transformation through cultivation-dependent strategy demonstrates the enrichment as well as the proportion of AOB and NOB in nitrifiers community. The developed strategy can quantify the exerted organic metabolites such as EPS and SMP in microbial-involved wastewater treatment processes. BAP generations were remarkably higher than UAP in either nitritation or nitratation. The portions of $A O B$ in microbial products were substantially higher than NOB, which might prove the far higher duty of cooperation to supply heterotrophic feed in activated sludge-involved process. The perfect positive correlation between AOB and microbial metabolites introduced an approach, and 
control of $\mathrm{C} / \mathrm{N}$ ratio in boom and bust cycle can prolong the nitratation process.

\section{Compliance with ethical standards}

Conflict of interest The authors declare that they have no conflict of interest.

Open Access This article is distributed under the terms of the Creative Commons Attribution 4.0 International License (http://creativeco mmons.org/licenses/by/4.0/), which permits unrestricted use, distribution, and reproduction in any medium, provided you give appropriate credit to the original author(s) and the source, provide a link to the Creative Commons license, and indicate if changes were made.

\section{References}

Adav SS, Lee D-J, Tay J-H (2008) Extracellular polymeric substances and structural stability of aerobic granule. Water Res 42:16441650. https://doi.org/10.1016/J.WATRES.2007.10.013

Barker DJ, Stuckey DC (1999) A review of soluble microbial products (SMP) in wastewater treatment systems. Water Res 33:3063-3082. https://doi.org/10.1016/S0043-1354(99)00022-6

Blackburne R, Vadivelu VM, Yuan Z, Keller J (2007) Determination of growth rate and yield of nitrifying bacteria by measuring carbon dioxide uptake rate. Water Environ Res 79:2437-2445

Carrera J, Torrijos M, Baeza JA, Lafuente J, Vicent T (2003) Inhibition of nitrification by fluoride in high-strength ammonium wastewater in activated sludge. Process Biochem 39:73-79. https://doi. org/10.1016/S0032-9592(02)00313-8

Dolinšek J, Lagkouvardos I, Wanek W, Wagner M, Daims H (2013) Interactions of nitrifying bacteria and heterotrophs: identification of a micavibrio-like putative predator of Nitrospira spp. Appl Environ Microbiol 79:2027-2037. https://doi.org/10.1128/ AEM.03408-12

Dytczak MA, Londry KL, Oleszkiewicz JA (2008) Activated sludge operational regime has significant impact on the type of nitrifying community and its nitrification rates. Water Res 42:2320-2328. https://doi.org/10.1016/J.WATRES.2007.12.018

Ekama GA, Marais GVR, Siebritz IP, Pitman AR, Keay GFP, Buchan L, Gerber A, Smollen M (1984) Theory, design and operation of nutrient removal activated sludge processes

Fang F, Ni B-J, Li X-Y, Sheng G-P, Yu H-Q (2009) Kinetic analysis on the two-step processes of AOB and NOB in aerobic nitrifying granules. Appl Microbiol Biotechnol 83:1159-1169. https://doi. org/10.1007/s00253-009-2011-y

Hu Z, Wentzel M, Ekama G (2003) Modelling biological nutrient removal activated sludge systems - a review. Water Res 37:34303444. https://doi.org/10.1016/S0043-1354(03)00168-4

Hunt KA, Jennings RM, Inskeep WP, Carlson RP (2018) Multiscale analysis of autotroph-heterotroph interactions in a high-temperature microbial community. PLoS Comput Biol 14:e1006431. https ://doi.org/10.1371/journal.pcbi.1006431

Jarusutthirak C, Amy G (2006) Role of soluble microbial products (SMP) in membrane fouling and flux decline. Environ Sci Technol 40:969-974. https://doi.org/10.1021/es050987a

Jia XS, Furumai H, Fang HHP (1996) Extracellular polymers of hydrogen-utilizing methanogenic and sulfate-reducing sludges. Water Res 30:1439-1444. https://doi.org/10.1016/0043-1354(96)00028 $-0$
Jiang T, Myngheer S, Depauw D, Spanjers H, Nopens I, Kennedy M, Amy G, Vanrolleghem P (2008) Modelling the production and degradation of soluble microbial products (SMP) in membrane bioreactors (MBR). Water Res 42:4955-4964. https://doi. org/10.1016/j.watres.2008.09.037

Keen GA, Prosser JI (1987) Steady state and transient growth of autotrophic nitrifying bacteria. Arch Microbiol 147:73-79. https://doi. org/10.1007/BF00492908

Kim J-H, Guo X, Park H-S (2008) Comparison study of the effects of temperature and free ammonia concentration on nitrification and nitrite accumulation. Process Biochem 43:154-160

Kindaichi T, Ito T, Okabe S (2004) Ecophysiological interaction between nitrifying bacteria and heterotrophic bacteria in autotrophic nitrifying biofilms as determined by microautoradiography-fluorescence in situ hybridization. Appl Environ Microbiol 70:1641-1650. https://doi.org/10.1128/ AEM.70.3.1641-1650.2004

Kowalchuk GA, Stephen JR (2001) Ammonia-oxidizing bacteria: a model for molecular microbial ecology. Annu Rev Microbiol 55:485-529

Krasner SW, Westerhoff P, Chen B, Rittmann BE, Nam S-N, Amy $G$ (2009) Impact of wastewater treatment processes on organic carbon, organic nitrogen, and DBP precursors in effluent organic matter. Environ Sci Technol 43:2911-2918. https://doi. org/10.1021/es802443t

Kunacheva C, Soh YNA, Trzcinski AP, Stuckey DC (2017) Soluble microbial products (SMPs) in the effluent from a submerged anaerobic membrane bioreactor (SAMBR) under different HRTs and transient loading conditions. Chem Eng J 311:72-81. https ://doi.org/10.1016/J.CEJ.2016.11.074

Le-Clech P, Chen V, Fane TA (2006) Fouling in membrane bioreactors used in wastewater treatment. J Memb Sci 284:17-53

Ma J, Wang Z, Zhu C, Liu S, Wang Q, Wu Z (2013) Analysis of nitrification efficiency and microbial community in a membrane bioreactor fed with low COD/N-ratio wastewater. PLoS ONE 8:e63059

Massot A, Estève K, Noilet $\mathrm{P}$, Méoule $\mathrm{C}$, Poupot $\mathrm{C}$, Mietton-Peuchot M (2012) Biodegradation of phytosanitary products in biological wastewater treatment. Water Res 46:1785-1792. https://doi. org/10.1016/J.WATRES.2011.12.055

Melcer H (2004) Methods for wastewater characterization in activated sludge modelling. IWA Publishing, Cambridge

Merkey BV, Rittmann BE, Chopp DL (2009) Modeling how soluble microbial products (SMP) support heterotrophic bacteria in autotroph-based biofilms. J Theor Biol 259:670-683. https://doi. org/10.1016/j.jtbi.2009.05.010

Mertoglu B, Calli B, Inanc B, Ozturk I (2006) Evaluation of in situ ammonia removal in an aerated landfill bioreactor. Process Biochem 41:2359-2366. https://doi.org/10.1016/j.procb io.2006.06.014

Ni B-J, Rittmann BE, Yu H-Q (2011) Soluble microbial products and their implications in mixed culture biotechnology. Trends Biotechnol 29:454-463

Okabe S, Satoh H, Watanabe Y (1999) In situ analysis of nitrifying biofilms as determined by in situ hybridization and the use of microelectrodes. Appl Environ Microbiol 65:3182-3191

Peng Y, Zhu G (2006) Biological nitrogen removal with nitrification and denitrification via nitrite pathway. Appl Microbiol Biotechnol 73:15-26

Raimonet M, Vilmin L, Flipo N, Rocher V, Laverman AM (2015) Modelling the fate of nitrite in an urbanized river using experimentally obtained nitrifier growth parameters. Water Res 73:373-387. https ://doi.org/10.1016/J.WATRES.2015.01.026

Rice EW, Bridgewater L, Association APH (2012) Standard methods for the examination of water and wastewater. Am Pub Health Assoc Wash, DC

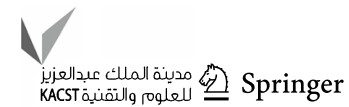


Schramm A, Larsen LH, Revsbech NP, Ramsing NB, Amann R, Schleifer KH (1996) Structure and function of a nitrifying biofilm as determined by in situ hybridization and the use of microelectrodes. Appl Environ Microbiol 62:4641-4647

Sepehri A, Sarrafzadeh M-H (2018) Effect of nitrifiers community on fouling mitigation and nitrification efficiency in a membrane bioreactor. Chem Eng Process Process Intensif 128:10-18. https ://doi.org/10.1016/j.cep.2018.04.006

Shariati FP, Mehrnia MR, Sarrafzadeh MH, Rezaee S, Grasmick A, Heran M (2013) Fouling in a novel airlift oxidation ditch membrane bioreactor (AOXMBR) at different high organic loading rate. Sep Purif Technol 105:69-78. https://doi.org/10.1016/j.seppu r.2012.12.008

Silva LCF, Lima HS, Sartoratto A, de Sousa MP, Torres APR, de Souza RS, de Paula SO, de Oliveira VM, da Silva CC (2018) Effect of salinity in heterotrophic nitrification/aerobic denitrification performed by acclimated microbiota from oil-produced water biological treatment system. Int Biodeterior Biodegradation 130:1-7. https://doi.org/10.1016/J.IBIOD.2018.03.009

Su Y (2012) Settleable algal-bacterial culture for municipal wastewater treatment. Universität Lüneburg, Alemania

Vadivelu VM, Keller J, Yuan Z (2006a) Stoichiometric and kinetic characterisation of Nitrosomonas sp. in mixed culture by decoupling the growth and energy generation processes. J Biotechnol 126:342-356. https://doi.org/10.1016/j.jbiotec.2006.04.017

Vadivelu VM, Yuan Z, Fux C, Keller J (2006b) Stoichiometric and kinetic characterisation of Nitrobacter in mixed culture by decoupling the growth and energy generation processes. Biotechnol Bioeng 94:1176-1188

Xie W-M, Ni B-J, Seviour T, Sheng G-P, Yu H-Q (2012) Characterization of autotrophic and heterotrophic soluble microbial product
(SMP) fractions from activated sludge. Water Res 46:6210-6217. https://doi.org/10.1016/j.watres.2012.02.046

Xie W-M, Ni B-J, Seviour T, Yu H-Q (2013) Evaluating the impact of operational parameters on the formation of soluble microbial products (SMP) by activated sludge. Water Res 47:1073-1079. https://doi.org/10.1016/j.watres.2012.11.022

Xie W-M, Ni B-J, Sheng G-P, Seviour T, Yu H-Q (2016) Quantification and kinetic characterization of soluble microbial products from municipal wastewater treatment plants. Water Res 88:703-710. https://doi.org/10.1016/J.WATRES.2015.10.065

Yao Q, Peng D-C (2017) Nitrite oxidizing bacteria (NOB) dominating in nitrifying community in full-scale biological nutrient removal wastewater treatment plants. AMB Exp 7:25. https://doi. org/10.1186/s13568-017-0328-y

Zeng D, Miao J, Wu G, Zhan X (2018) Nitrogen removal, microbial community and electron transport in an integrated nitrification and denitrification system for ammonium-rich wastewater treatment. Int Biodeterior Biodegrad 133:202-209. https://doi.org/10.1016/J. IBIOD.2018.07.014

Zhang D, Zhou Y, Bugge TV, Mayanti B, Yang A, Poh LS, Gao X, Majid M, bin Abdul Majid M, Ng WJ (2017) Soluble microbial products (SMPs) in a sequencing batch reactor with novel cake filtration system. Chemosphere 184:1286-1297. https://doi. org/10.1016/j.chemosphere.2017.06.110

Publisher's Note Springer Nature remains neutral with regard to jurisdictional claims in published maps and institutional affiliations. 